\title{
Growth and breeding of aspen in Russia
}

\author{
By Anatoly P. Tsarev*)
}

(Received 27 $7^{\text {th }}$ September 2011)

\begin{abstract}
Researches results are presented that describe variation in natural aspen stands and hybrid collections in Central European Russia. The subject of the study was the selection of the most productive and resistant to heart rot caused by fungus Phellinus tremulae (Fomes igniarius) stands. Mechanical wood properties, fodder values and other valuable characteristics of aspen are also shown. The valuable stands and hybrids which require conservation were selected for breeding and practical use.
\end{abstract}

Key words: aspen, heart rot resistant, breeding, hybrids, forms, mechanical properties, fodder value.

\section{Introduction}

European aspen (Populus tremula L.) is the second most common deciduous species after birch (Betula pendula Roth) among natural stands of Russia in terms of the extent of their natural habitat and the volume of merchantable volume. European aspen is a multi-purpose species. Its wood is white, flavorless and does not shrink appreciably when dried. Its markets include matches and packing material, construction, and pulp and paper. European aspen is also important as a pollen source for honey production. The vigorous production of root suckers has promoted European aspen as a preferred species for afforesting hillsides and other marginal sites. (YABLOKOV, 1963; WORRELL, 1995; KREMER, 1998; BACHOFER and MAYER, 2007; WÜHLISCH, 2009).

The Russian aspen resource is the largest in the world. The country's natural habitat of European aspen covers $23,795,000$ hectares with a standing volume 3.7 billion cubic meters, not accounting for those stands where it occurs in mixtures with other species. This area has expanded by 9.9 million ha, or $71 \%$ during the last 50 years (YABLOKOV, 1963; Distribution..., 2011). The increase in aspen stands is owing to two main reasons: 1) Stands of mixed species composition containing as few as three aspens per hectare will regenerate to pure aspen stands due to aggressive root suckering following logging (YABLOKOV, 1963); 2) Lack of artificial regeneration programs for Russia's other commercial species: Scotch pine (Pinus sylvestris L.), Sprus (Picea sp.) and Oak (Quercus robur), where they occur in mixtures with aspen.

The greatest area of aspen stands is situated in the southern part of the forest zone of the European part of Russia, in the forest-steppe and in the south of Western

\footnotetext{
*) Corresponding author: Anatoly P. TSAREv. Dr. Agricultural Sc. Professor of Forest Engineering Faculty, Forestry Chair, Petrozavodsk State University, 33 Lenin pr., Petrozavodsk, 185910, Karelia, Russia. Tel.: +7-8142-560753, fax: +7-8142 711000. E-Mail: antsa_55@yahoo.com; tsarev@psu.karelia.ru.
}

Siberia, where they replace primary stands of basic trees and form secondary stands replacing the previous climax forests. Aspen stands grow mainly in the Composita, Oxalidosum and Myrtillosum forest types. In general, aspen grows on medium rich and rich soils with normal or wet moisture conditions. It is not found in forests on poor or dry soils (Cladinosa forest type). It is seldom found in forests on somewhat poor dry soils (Vacciniosum forest type). Aspen grows in forests which are temporarily-flooded or have stagnant soil moisture (Polytrichosa forest type) but it forms unmerchantable, short-lived stands as also in forests with high moisture content in soil (Carex forest type), where it suffers severely from root rot. Aspen does not grow on peat bogs. It grows in the mixture of all types of broadleaf forests. Aspen stands in the forest zone include an admixture of forest tree species found in primary forests (spruce, fir, pine, oak, linden etc.), and sometimes also birches and alders (fig. 1). In small hollows in steppe conditions, aspen can be found in small blocks of pure natural stands called aspen "kolky".

The aspen stands are diverse in composition and structure on normal fresh humus of loamy podzols over blanket loam. Many aspen forests have three layers: the main layer consists of aspen and some birch; the second layer consists of spruce, oak, gray alder; the third layer is presented by the ground vegetation. Live ground vegetation cover in these forests consists mainly of majanthemum, nettle, goutweed, oxalis, fern, and meadow sweet.

Due to its ability to propagate by root suckers aspen quickly captures the area released after cutting. In the second year after cutting, there are a great many root suckers. Because of the very large number of stems on a unit area and light-demanding nature of aspen, its stands undergo intensive natural thinning from an early age. By the age of 10 years, the volume of stem-wood amounts to $40-50 \mathrm{~m}^{3} / \mathrm{ha}$; by the age of 30 years it increase by $3-4$ times $\left(150-200 \mathrm{~m}^{3} / \mathrm{ha}\right)$; and by the age of 70 years the volume reaches $500-550 \mathrm{~m}^{3} / \mathrm{ha}$. In stands growing in particularly favorable conditions, the average volume at the age of 70 years may reach $650 \mathrm{~m}^{3} /$ ha. The quantitative maturity is registered at the age of 25-30 years, technical maturity - at the age of 35 years. Maximum mean annual increment is reached at the age of 40 years. In top quality stands it may be $2.9-3.9 \mathrm{~m}^{3} / \mathrm{ha} / \mathrm{yr}$ in the centre of the species natural habitat and more then $5-7 \mathrm{~m}^{3} / \mathrm{ha} / \mathrm{yr}$ in the Central Chernozem region (fig. 2).

In different European countries the mean annual increment may vary in the range $4-10 \mathrm{~m}^{3} / \mathrm{ha} / \mathrm{yr}$ (WORRELL, 1995). G. WÜHLISCH (2009) is mentioning that aspen trees can grow to $40 \mathrm{~m}$ height with a trunk attaining over one meter in diameter. 


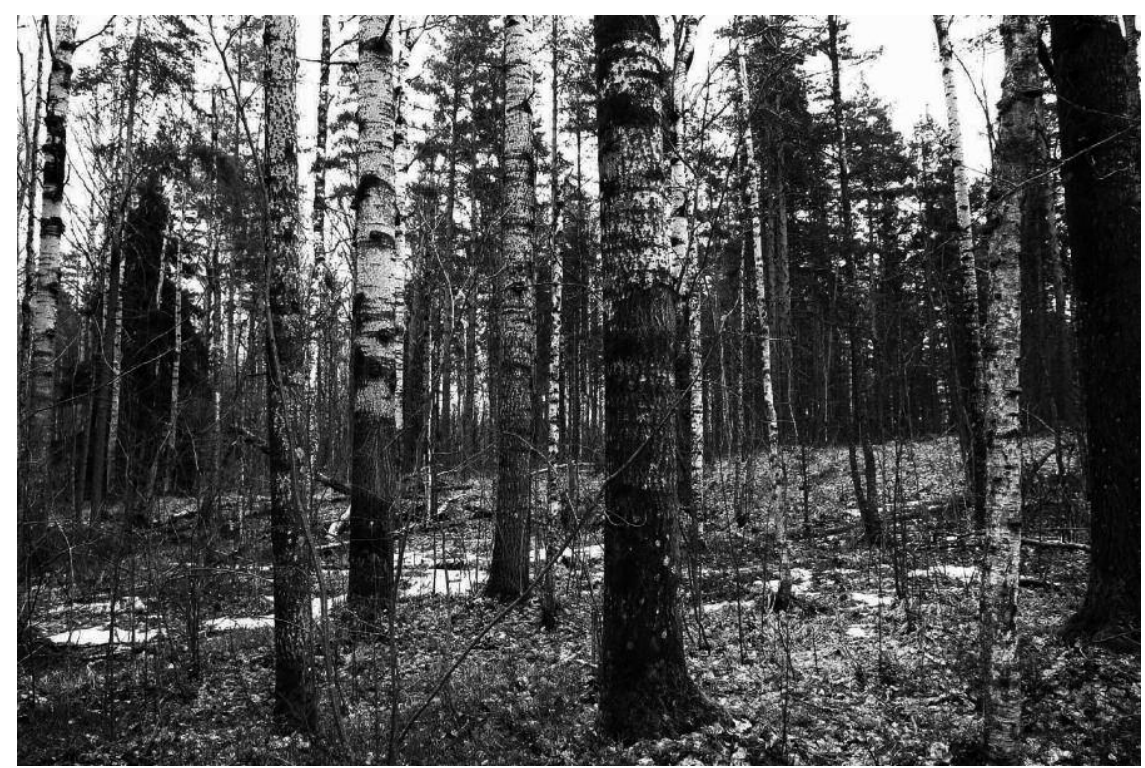

Figure 1. - The mixed composition stand of aspen, pine and spruce in Russia's European middle taiga, Konchezero, Republics of Karelia. Photo courtesy of N. V. LAUR

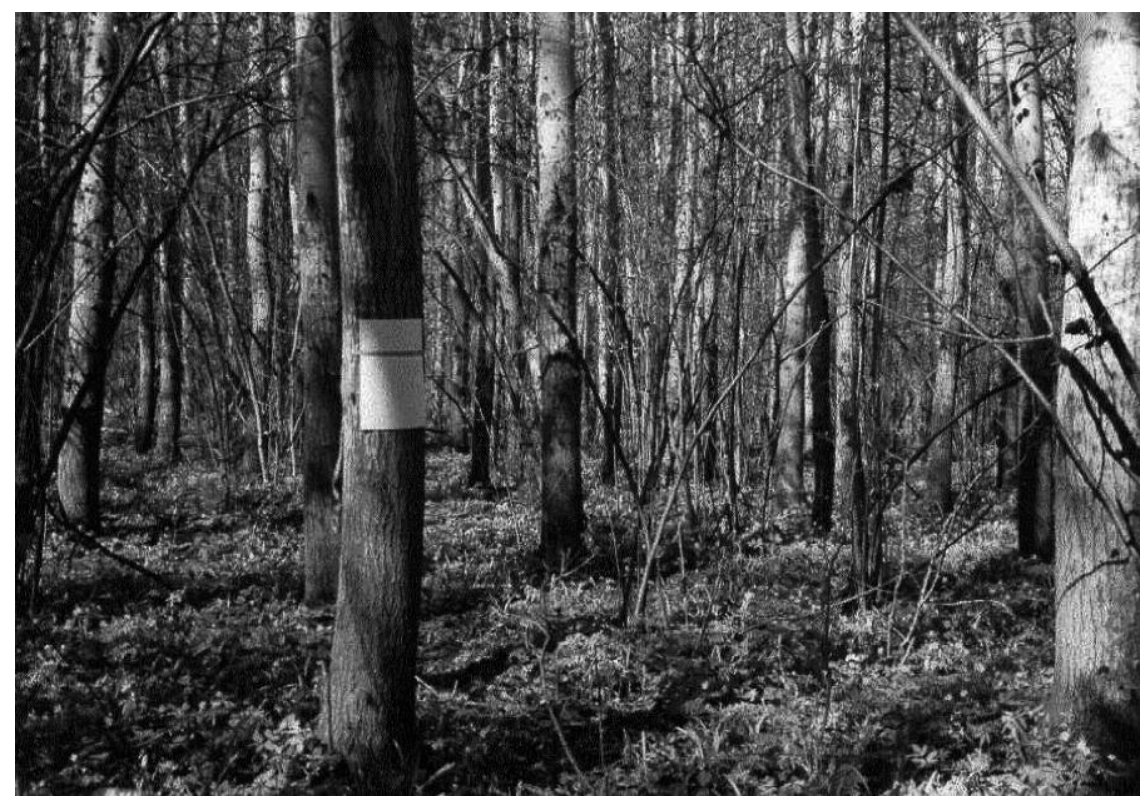

Figure 2. - Central Chernozem aspen stand in zone Voronezh region. The volume at age 40 is $300 \mathrm{~m}^{3} / \mathrm{ha}$. The number of trees infected by heart rot is $25 \%$. Forest site type is $\mathrm{D} 2$.

Photo courtesy A. P. TSAREV

Harvesting of aspen stands is normally carried out by clear cuttings. The age of stands at clear-cutting varies depending on their state from 41 to 60 years. The normal harvesting rotation provides natural regeneration after clear-cutting. If a viable spruce is present under the storey of aspen stands then cutting of aspen will be undertaken with the objective of coniferous species conservation.

Natural forests with aspen dominant are generally secondary in succession, i. e. they grow after cutting or fire in place of spruce, pine, oak or other broadleaved species. The majority of these forests originate from root suckers and partly from stem shoots. Part of these aspen stands is seed-originated (TREes..., 1951; YABLOKOV, 1963).

The research in the Central forest-steppe of the European part of Russia has shown that, compared with some other forest species, the productivity of aspen on a given site depends more on soil moisture conditions than on soil fertility (TSAREV, 1970).

Plantations of aspen are established by sowing seed, setting root cuttings and roots or transplanting root suckers. Many investigations were carried out with P. tremula in Russia and European countries and with P. tremuloides in North America to improve the striking roots of planting materials and growth of trees and to 
find the heritability and growth gain in different conditions ((IVANNIKOV, 1958; BöRSET, 1960; YABLOKOV, 1963; (Ahuja, Muhs, 1982; Muhs, 1987; Muhs, Wuehlisch, 1990 - cited by WÜHLISCH, 2006); WORRELL, 1995; Thomas, 1997; David, 2003; Des Roshers et al., 2003; TSAREva, 2003; HeInZE and Fussi, 2010; TsARev et al., 2011)).

A limitation to aspen domestication is heart rot. The causative agent of this illness is mushroom Phellinus tremulae (Bond.) Bond. et Boriss. (Fomes igniarius $f$. tremulae Bond.). This is included in the Fungi type, Basidiomycota division, Agaricomicotina subdivision, the class Agaricomicetes, Hymenochaetales order, Hymenochaetaceae family, the genus Phellinus.

Fruit bodies look like a narrow hat with the high basis, a keen edge and small longitudinal cracks. Very often they have a prostrate form especially if they appear on branches. Usually they grow in places of disappeared knots. Decay is concentrated in the central part of a trunk, settling down differently. On cross-sections of a trunk the decay has the following appearance: yellow-white strongly destroyed wood in the form of a wrong circle with scattered brownish closed or interrupted thin black lines is located in the central part of a trunk. Decay is separated from the healthy part by a wide - from 2 to $4 \mathrm{~mm}$ - brown ring-shaped strip. A ring-shaped green strip of wound nuclear wood up to 1 $\mathrm{cm}$ wide circulates the brown strip and is well visible on fresh cuts (VANIN, 1955). More detailed description of its culture and wood affection is given by $\mathrm{T}$. Niemelä, L. Ryvarden \& R. L. Gilbertson in Fungal databases (2004-2012).

Damage caused by heart rot can affect up to $100 \%$ of the trees within a stand. Consequently the selection of a resistant individuals and stands is a priority task in aspen cultivation. Other traits including productivity and wood, quality of wood are considered as well.

\section{Materials and Methods}

General characteristics of aspen stands in Russia are based on author's personal research data and partly on literature sources.

Selection of stands resistant to attack of heart rot, investigation of aspen growth depending on forest types, research of physical and mechanical characteristics were carried out in Voronezh region.

The investigation of natural aspen stands was carried out in massifs of the Educational and Skilled Forest Enterprise of the Voronezh State Forest-Technical Academy, the Voronezh State and Hopersky State national parks, and the Savalsky, Hrenovskoy, Tellermanovsky and Anninsky forestry enterprises, all of which are situated in the northeast forest-steppe part of the Voronezh region. These massifs are located on the border of foreststeppe and steppe zones. The latitude is $51-52^{\circ}$ of North and $39-42^{\circ}$ of East. The total area of aspen forests in these farms accounts for over 17 thousand hectares.

Mean annual precipitation is $450 \mathrm{~mm}$. Mean annual temperature is $+5^{\circ} \mathrm{C}$. The predominant soil type varies from grey forest soils to chernozems. The depth to the water table is quite variable. It is allocate three types of ground waters: 1) ground waters of watersheds with a depth from 2-3 to $10-15 \mathrm{~m} ; 2$ ) ground waters of the slopes, which depth depends on a land relief and on the power of the diluvial cover covering radical deposits, which replenishment happens at the expense of an atmospheric precipitation and an underground drain and 3) ground waters of alluvial deposits of valleys. Comparative experiments as described below were carried out in the same or similar environments.

Investigation to identify superior phenotypes was conducted using both basic and advanced techniques. Basic techniques involved usual inventory data (structure, average height, average diameter, stock, age, etc.). The advanced techniques involved in addition to inventory data a value of affecting by heartwood decay and the degree of stem straightness. Stands covering 2,000 hectares were inventoried by the basic method. In contrast, a more sophisticated technique was used in inventorying 675 separate sites totaling 890 hectares in forests of Educational and Skilled Forest Enterprise of the Voronezh State Forest-Technical Academy and 200 hectares in the other forestry enterprises. The procedure involved the collection of data on the relief, soil, heart decay, sex, character of bark, crown, branching of trunks in addition to the standard inventory characteristics.

Thirty-two (32) study plots varying in area from 0.15 to 0.60 hectares were designed to obtain exact measurements of phenotypic characteristics. The distribution of trees within each study plot categorized according to of trunk quality (good, semi-good and firewood), heart rot attack, growth classes - from I (most great) to V (weaken and least) (by Kraft, 1884 - to quoted by M. S. Melekhov, 1980), sex and other characteristics (phenological form, type and color of rind, form and size of crowns, character of branches, cleaning from branches, defeat of diseases and insects). A detailed description of the relief, soil, herb cover, undergrowth was given.

One hundred forty (140) trees were destructively sampled on all plots. Each tree was cut on two-meter sections. The diameter of sound and decay wood were measured in middle of each sections. In addition increment cores were removed from 20-30 trees in each plot to improve the accuracy of heart rot attack evaluation.

Physical and mechanical wood properties were tested in two decay resistant stands of aspen. In total 1321 samples were tested. Density, compression strength along fibers, strengths in static bending and in shock bending was established. Wood density measurements were reported on a dry weight volume basis. Modeling trees and section from them as the testing was taken and made according I. V. Yakimov (1964). The average data of physical and mechanical wood properties of Voronezh region aspen stands (YAKIMOV, 1964) were taken as control.

Studies of aspen hybrids reported in the article were carried out in field trials established in Semiluksky nursery in Voronezh region on chernozem soil by V. P. Petruchnov (TSAREV and TSAREV, 2010). The type of forest environments is $D_{1-2}$. The design of the experiment did not include repetitions. Each hybrid family consisted 
of 32-68 hybrid trees. The spacing of trees was $3 \times 3 \mathrm{~m}$. Area of that collection is 0.934 ha. That Semiluksky collection includes next hybrid families: P. tremula $\mathrm{X}_{1} \mathrm{x}$ P. tremula (local), P. tremula $\mathrm{X}_{2} \times P$. tremula (local), $P$. tremula (Obojan) $\mathrm{x} P$. canescens, $P$. tremuloides $\mathrm{x}$ $P$. tremula (local), $P$. tremuloides x $P$. alba var. bolleana, $P$. canescens $\times$ P. tremula (local), $P$. davidiana $\times$ P. tremula (local), $P$. davidiana $\mathrm{x} P$. alba var. bolleana, $P$. 'Yablokovy' $x$ P. canescens and offspring from open pollinated two species: Populus tremula and Populus davidiana. $P$. tremula $\mathrm{X}_{1}$, P. tremula $\mathrm{X}_{2}$, P. tremula (local) and $P$. canescens were selected in stands of the Educational and Skilled Forest Enterprise of the Voronezh State Forest-Technical Academy. The P. davidiana was taken from Semiluksky arboretum of Central Research Institute of Forest Genetics and Breeding (Voronezh). The P. tremuloides, the cultivar P. 'Yablokov' and one clone of $P$. tremula introduced from Obojan city of Kursky region. P. alba var. bolleana Lauche introduced from Astrakhan region. The halfsibs of $P$. tremula (local) and $P$. davidiana were taken as control. Survival, height and basal diameter at height $1.3 \mathrm{~m}$ data were collected at age 29. Stems volume was defined according to aspen volumes table reported by TYURIN et al. (1956).

The volume of family stands on the area was defined by summation of the actual volumes of each tree remaining on each plot. Stand volume was expressed on the basis of one hectare. The following formula was used:

$$
\mathrm{W}=\mathrm{W}^{\prime} \times 10000 / \mathrm{S},
$$

where: $\mathrm{W}$ - accounted stem wood volume, $\mathrm{m}^{3} / \mathrm{ha}$;

$\mathrm{W}^{\prime}$ - actual stem wood volume on plot area, $\mathrm{m}^{3}$;

$\mathrm{S}$ - area of the plot, occupied by one hybrid family, $\mathrm{m}^{2}$

10000 - area of one hectare, $\mathrm{m}^{2}$.

Stem wood volume of each hybrid family was defined according to these factors.

Selected components of aspen green mass (leaves, stalks and shoots) that account for its fodder value were quantified by the fodder laboratory of Voronezhsky Regional Agriculture Chemical Station, Data were collected for digestible proteins, nitrogen, calcium, phosphorus, and carotene and were studied. The contents of calcium, carotene, and phosphorus were determined by the photo colorimetric method, Zirel's method, and the vanadium-molybdenum method, respectively, according to recommendation reported by RAZUMOV (1986).

Besides of that an integral fodder value was obtained as the number of fodder units per $1 \mathrm{~kg}$ of food. The Russian fodder unit designed by E. A. Bogdanov in 1922 equals $1 \mathrm{~kg}$ of oat or $0.6 \mathrm{~kg}$ of starch (ZIPER, 2003). In present work the oat fodder unit was used for estimation of fodder value.

The alfalfa green mass was used as control.

\section{The results and discussion}

\subsection{Selection of aspen stands resistant to heart rot}

As it has been said above aspen stands are often subject to heart rot. The problem of distribution of aspen heart decay in European and Russian forests was investigated by many researchers (NILSSON-EHLE, 1936; MELANDER, 1938; Johnsson, 1942; YABLOKOV, 1941, 1949, 1963; IVANNIKOV, 1952, 1958; BAKULIN, 1966, 1969; TSAREV, 1970, 1985).

The dynamics of heart rot attack in Central foreststeppe is shown in the Table 1. Aspen heart rot begins in age class 2 (11-20 years) - about $0.6 \%$. By the time the stand has matured to 41-50 years of age (age class 5) $31.2 \%$ of the trees were found to be affected. In stands of age class 6 (51-60 years) $59.6 \%$ of the trees were affected. And in stands of age class 7 (61-70 years) $90.4 \%$ of the trees were affected.

The volume growth of sound wood in aspen stands in a given region generally declines up to 35 years, then the merchantable volume is reduced rapidly up to 50 years of age (up to $59 \%$ ), and in old stands is further reduced to $10 \%$ and even to zero. Thus, it is necessary to select aspen resistant to heart rot in order to produce healthy aspen stands with high productivity. Efforts to select aspen have been made in different regions of European and Asian parts of Russia. These resulted in the selection of aspen stands and clones resistant to heart rot (Table 2).

As shown in Table 2 there can be quite significant differences in heart rot attack and productivity in natural stands. So, in spite of similar growth conditions and age the mean infection rate of selected aspen stands is 17 times less than that of the control ones.

Table 1. - Dynamics of heart rot attack in aspen stands and proportion of sound wood in relation to age in Central Chernozem zone.

\begin{tabular}{|l|cc|c|c|c|cc|}
\multirow{2}{*}{ Parameters } & \multicolumn{7}{|c|}{ Agc class* } \\
\cline { 2 - 8 } & I & II & III & IV & V & VI & VII \\
\hline $\begin{array}{l}\text { Stems attacked by } \\
\text { heart rol, \% } \\
\text { Sound wood, \% of } \\
\text { total volume }\end{array}$ & 0 & 0.6 & 1.6 & 16.1 & 31.2 & 59.6 & 90.4 \\
\hline
\end{tabular}

* I age class of stands is 1-10 years old; II age class of stands is 11-20 years old; III age class of stands is 21-30 years old; IV age class of stands is 31-40 years old; V age class of stands is $41-50$ years old; VI age class of stands is $51-60$ years old; VII age class of stands is $61-70$ years old. 
Table 2. - Mean characteristics of plus aspen stands selected in the Voronezh region and usual aspen stands.

\begin{tabular}{|c|c|c|c|c|c|c|}
\hline $\begin{array}{l}\text { Experimental } \\
\text { stands }\end{array}$ & Values & $\begin{array}{l}\text { Age, } \\
\text { years }\end{array}$ & $\begin{array}{l}\text { Total } \\
\text { volume, } \\
\mathrm{m}^{3} / \mathrm{ha}\end{array}$ & $\begin{array}{l}\text { I leart rot } \\
\text { affection }\end{array}$ & $\begin{array}{l}\text { Sound } \\
\text { wood } \\
\text { volume, } \\
\mathrm{m}^{3} / \mathrm{ha}\end{array}$ & $\begin{array}{l}\text { Part of } \\
\text { sound } \\
\text { wood, } \%\end{array}$ \\
\hline \multirow[t]{2}{*}{ Plus stands } & mean & 45 & 370.0 & 3.8 & 244.8 & \multirow[t]{2}{*}{66.2} \\
\hline & limits & $43-46$ & $\begin{array}{l}341- \\
391\end{array}$ & $0-6.1$ & $\begin{array}{l}186- \\
295\end{array}$ & \\
\hline \multirow{2}{*}{$\begin{array}{l}\text { Usual stands } \\
\text { (control) }\end{array}$} & mean & 41 & 367.2 & 63.2 & 46.1 & \multirow[t]{2}{*}{12.6} \\
\hline & limits & $39-46$ & $\begin{array}{l}274- \\
475\end{array}$ & $\begin{array}{l}21.3- \\
91.1\end{array}$ & $9.5-82$ & \\
\hline
\end{tabular}

* Percentage of stems on which fruiting bodies of heart rot occurred.

This leads to the fact that when general wood volume in natural stands is similar or equal the volume of sound (merchantable) wood it is many times greater in selected aspen stands than in usual ones. The comparison of mean volume of sound wood on three plots of plus stands and that on three plots of control usual stands showed that the quantity of sound wood in plus stands was 5.2 times more than that in control stands (Table 2). Determination of the degree of genetic and environmental controls of this difference can be obtained by special testing research of offspring.

\subsection{Physical and mechanical wood properties of different aspen stands}

The sapwood of aspen is diffuse porous in structure, white in color with a greenish shade, light in density, and mild. Physical-mechanical parameters for two fastgrowing and heart-rot-resistant stand and for control stands in the Central forest-steppe are given in Table 3.

As it is shown in Table 3, the wood density of selected stands of Populus tremula L. and usual ones, in which no selection have been made, differ insignificantly $\left(0.502\right.$ and $\left.0.500 \mathrm{~g} / \mathrm{cm}^{3}\right)$ for the first pair of the test areas and differ significantly $\left(0.498\right.$ and $\left.0.450 \mathrm{~g} / \mathrm{cm}^{3}\right)$ in the second ones. It is interesting, that these figures are higher than those generally reported for the NorthAmerican species Populus tremuloides Michx. (0.39-0.42 $\mathrm{g} / \mathrm{cm}^{3}$ ) growing in its native environment (SCHREIBER et al., 2011).

The compression strength along fibers and the strength at static bend of the selected stands and usual ones differ significantly $(t=1.8-9.2)$ in favor of selecting

Table 3. - Physical and mechanical wood properties of different aspen stands (at $15 \%$ moisture content).

\begin{tabular}{|c|c|c|c|}
\hline \multirow[t]{2}{*}{ Properties } & $\begin{array}{l}\text { Selected heart-rot- } \\
\text { resistant stands of } \\
\text { aspen (from A. P. } \\
\text { Isarev) }\end{array}$ & $\begin{array}{l}\text { Usual stands of } \\
\text { aspen (from I. V. } \\
\text { Yakimov (1964) }\end{array}$ & \multirow[t]{2}{*}{$\begin{array}{l}\text { Coefficient } \\
\text { of } \\
\text { significance, } \\
t^{*}\end{array}$} \\
\hline & $\mathrm{X} \pm \mathrm{s}_{\mathrm{x}}$ & $\mathrm{X}=\mathrm{s}_{\mathrm{X}}$ & \\
\hline & $\begin{array}{c}\text { Experimental plot } \\
\text { a } 3, \text { forest site } \\
\text { type }{ }^{* *} C_{2}\end{array}$ & $\begin{array}{c}\text { Control, } \\
\text { forest site type } C_{3}\end{array}$ & \\
\hline Density of wood, $\mathrm{g} / \mathrm{cm}^{3}$ & $0.502 \pm 0.003$ & $0.500 \pm 0.004$ & - \\
\hline $\begin{array}{l}\text { Compression strength } \\
\text { along fibers, } \mathrm{kg} / \mathrm{cm}^{2}\end{array}$ & $359.0 \pm 2.63$ & $331.0 \pm 3.3$ & 6.7 \\
\hline $\begin{array}{l}\text { Strength at a static } \\
\text { bend, } \mathrm{kg} / \mathrm{cm}^{2}\end{array}$ & $673.0 \pm 9.55$ & $653.0 \pm 4.7$ & 1.8 \\
\hline \multirow{2}{*}{$\begin{array}{l}\text { Specilic work at a } \\
\text { shock bend, } \mathrm{kgm} / \mathrm{cm}^{3}\end{array}$} & $0.40 \pm 0.01$ & n. d. ${ }^{* * *}$ & n. d. \\
\hline & $\begin{array}{c}\text { Experimental plot } \\
\text { № } 12, \text { forest site } \\
\text { type } E_{3}\end{array}$ & $\begin{array}{c}\text { Control, } \\
\text { forest site type } D_{3}\end{array}$ & \\
\hline Density of wood, $\mathrm{g} / \mathrm{cm}^{3}$ & $0.498 \pm 0.003$ & $0.450 \pm 0.003$ & 11.4 \\
\hline $\begin{array}{l}\text { Compressing strength } \\
\text { along fibers, } \mathrm{kg} / \mathrm{cm}^{2}\end{array}$ & $355.0 \pm 2.5$ & $300.0 \pm 5.4$ & 9.2 \\
\hline $\begin{array}{l}\text { Strength at a static } \\
\text { bend, } \mathrm{kg} / \mathrm{cm}^{2}\end{array}$ & $655.0 \pm 10.8$ & $613.0 \pm 5.7$ & 4.3 \\
\hline $\begin{array}{l}\text { Specilic work al a } \\
\text { shock bend, } \mathrm{kgm} / \mathrm{cm}^{3}\end{array}$ & $0.47 \pm 0.016$ & n. d. & n. d. \\
\hline
\end{tabular}

*) At 0.05 level of significance;

**) Forest site types were determinate by P. S. PogrebnyaK (1968);

***) n. d. - no data. 
stands. It is mention that these data are average between minimal and maximal value of that characteristics. S. Eliseev and B. Ermolin (2008) were showed that in $P$. tremula the compression strength along fibers varied from 30.0 to $44.8 \mathrm{MPa}$ while in our research it varied from 35.5 to $35.9 \mathrm{MPa}$ at heart-rot resistant stands and from 30.0 to $33.1 \mathrm{MPa}$ at usual stands. The strength at static bend of the aspen stands as a full varied from 53.2 to $83.2 \mathrm{MPa}$ while in our research it varied from 65.5 to $67.3 \mathrm{MPa}$ at heart-rot resistant stands and from 61.3 to $65.3 \mathrm{MPa}$ at usual stands.

\subsection{Growth and resistance of aspen hybrids}

The best hybrid families of the Semiluksky aspen collection at 16 years of age had mean growth parameters of $14.6-15.1 \mathrm{~m}$ in height and $16.8-20.1 \mathrm{~cm}$ in stem diameter and stem volume $145-214 \mathrm{~m}^{3} \cdot 10^{-3}$ : these parameters exceed the control trees by $1,3-1,9$ times (TSAREVA, 2003).

As the result of the long-term trialing of the genotypes in the collections many proven hybrids have been selected both for industrial plantations and as breeding material for further complex crossings and development of new cultivars (TSAREV and TSAREV, 2010).

Among hybrid offspring of the aspen it was possible to select five best productivity families (Table 4).

Two of them were obtained by crossbreeding of local plus trees $\left[P\right.$. tremula $\mathrm{X}_{2} \times$ P. tremula (local), P. tremula $\mathrm{X}_{1} \times P$. tremula (local)] and three - by remote hybridization $[P$. tremuloides $\mathrm{x} P$. tremula (local), $P$. tremuloides $\mathrm{x}$ $P$. alba var. bolleana and $P$. tremula (Obojan) $\mathrm{x}$ $P$. canescens]. The average volume of stem wood determined in these families at the age of 29 years varied from 223 to $508 \mathrm{~m}^{3} /$ ha. Heart-rot infected trees at this age were not evident. More than 60 perspective hybrids were selected. Their height at this age varied from 19 to $25 \mathrm{~m}$, average diameter - varied from 25 to $40 \mathrm{~cm}$, and stem volume varied from 0.4 to $1.1 \mathrm{~m}^{3}$. These hybrids did not culminate merchantable growth and their wood volume was projected continue to increase. Thereby, the hybrid aspen stands could supply about $500 \mathrm{~m}^{3} /$ ha of wood already at the age of 30 years. All trees at this age were sound.

Similar experiments conducted in Germany also report that the aspen hybrids are superior to pure species selections (WÜHLISCH, 2006, 2010; UNSELD and WÜHLISCH, 2012).

\subsection{Fodder value of aspen}

Analyses of food value of aspen green mass in foreststeppe region of the European part of Russia showed that it contained $0.14-0.35$ fodder units per kg depending on its composition (leaves, stalks or branches) and moisture. The greatest quantity of fodder units was in shoots of young aspen scions $(0.29-0.35$ fodder units per $\mathrm{kg}$ ). Leaves contained $0.25-0.29$ fodder units $/ \mathrm{kg}$, and the lowest quantity was in stalks: $0.14-0.24$ fodder units $/ \mathrm{kg}$. The food value of alfalfa varied from 0.24 (field moisture) to 0.49 (hay) fodder units/kg (Table 5).

The content of digestible protein varied from $9.0 \mathrm{~g} / \mathrm{kg}$ in stalks to $32 \mathrm{~g} / \mathrm{kg}$ in leaves. It was less than that of alfalfa $(34-40 \mathrm{~g} / \mathrm{kg})$. The calcium content did not differ significantly from that of alfalfa. The concentration in fresh green mass of aspen was $3.15-14.92 \mathrm{~g} / \mathrm{kg}$, while in fresh mass of alfalfa it was $4.5-5.04 \mathrm{~g} / \mathrm{kg}$. But the content of this ingredient in absolutely dried alfalfa reached $19.3 \mathrm{~g} / \mathrm{kg}$. The aspen content of phosphorus varied from 0.59 to $1.52 \mathrm{~g} / \mathrm{kg}$. It was more than in fresh alfalfa $(0.64-0.70 \mathrm{~g} / \mathrm{kg})$ but less than in absolutely dried alfalfa $(2.5 \mathrm{~g} / \mathrm{kg})$ or in alfalfa hay $(2.21 \mathrm{~g} / \mathrm{kg})$. The content of carotene in aspen green mass was $28-75 \mathrm{mg} / \mathrm{kg}$. In fresh alfalfa it was $29-96 \mathrm{mg} / \mathrm{kg}$ and in alfalfa hay $20-86 \mathrm{mg} / \mathrm{kg}$.

So the aspen green mass is comparable with alfalfa green mass.

Table 4. - The average growth indices of aspen hybrid families in Semiluksky collection of Voronezh region at age 29 years.

\begin{tabular}{|c|c|c|c|c|c|c|c|c|c|c|}
\hline \multirow{2}{*}{ Hybrid families of aspen } & \multirow{2}{*}{$\begin{array}{l}\text { Planted, } \\
\text { seedlings }\end{array}$} & \multirow{2}{*}{$\begin{array}{c}\text { Survival, } \\
\%\end{array}$} & \multicolumn{2}{|c|}{ Growth indices } & \multicolumn{2}{|c|}{$\begin{array}{c}\text { Mean stem } \\
\text { volume }\end{array}$} & \multirow{2}{*}{$\begin{array}{l}\text { The size } \\
\text { of family } \\
\text { plots, } \mathrm{m}^{2}\end{array}$} & \multirow[t]{2}{*}{$\begin{array}{c}\text { Wood } \\
\text { volume } \\
\mathrm{m}^{3} / \mathrm{ha}\end{array}$} & \multicolumn{2}{|c|}{ Wood volume, } \\
\hline & & & $\begin{array}{l}\text { Mean } \\
\text { hoight, } \\
\text { m }\end{array}$ & $\begin{array}{c}\text { Mean } \\
\text { diameter, } \\
\text { cm }\end{array}$ & $\mathrm{m}^{3}$ & rank & & & rank & $\%$ \\
\hline P. tremuloides x P. tremula (local) & 147 & 49.7 & 18.5 & 24.3 & 0.42 & 4 & 1150 & 267 & 3 & 156 \\
\hline P. davidiana x $P$. tremula (local) & 168 & 41.1 & 16.8 & 21.2 & 0.29 & 8 & 1300 & 156 & 9 & 91 \\
\hline P. davidiana $x$ P. alba nam bolleana & 89 & 44.9 & 16.3 & 20.3 & 0.26 & 10 & 810 & 129 & 10 & 75 \\
\hline P. tremila, $X_{I} \times P$. tremula (local) & 148 & 81.8 & 17.5 & 22.4 & 0.34 & 6 & 1550 & 266 & 4 & 156 \\
\hline P. tremila, $X_{2} \times$ P. tremula (local) & 50 & 80.0 & 19.2 & 25.9 & 0.50 & 2 & 390 & 508 & I & 297 \\
\hline P. tremuloides $\times$ P. alba var, bolleana & 32 & 43.8 & 18.0 & 23.3 & 0.38 & 5 & 160 & 331 & 2 & 194 \\
\hline P. canescens $\mathrm{x} P$. tremila (local) & 150 & 43.3 & 17.0 & 21.6 & 0.31 & 7 & 1010 & 199 & 7 & 116 \\
\hline P. 'Yablokovy' x P. canescens & 60 & 46.7 & 18.6 & 24.3 & 0.42 & 3 & 580 & 204 & 6 & 119 \\
\hline P. tremula, Obojan $x P$. canescens & 40 & 42.5 & 20.1 & 28.0 & 0.60 & 1 & 460 & 223 & 5 & 130 \\
\hline P. tremula (local, halfsibs, control) & 136 & 54.4 & 16.7 & 20.9 & 0.28 & 9 & 1230 & 171 & 8 & 100 \\
\hline P. davidiana (halfsibs) & 73 & 41.1 & 15.6 & 18.4 & 0.21 & 11 & 700 & 88 & 11 & 51 \\
\hline Total and average & 1093 & 52.2 & & & & & 9340 & & & \\
\hline
\end{tabular}


Table 5. - Compositional analysis of aspen green mass for fodder value.

\begin{tabular}{|c|c|c|c|c|c|c|c|}
\hline \multirow[t]{2}{*}{ Fodder Source } & \multirow{2}{*}{$\begin{array}{c}\text { Number } \\
\text { of } \\
\text { analyzed } \\
\text { samples }\end{array}$} & \multicolumn{5}{|c|}{ Content in one kilogram of natural moisture fodder } & \multirow{2}{*}{$\begin{array}{c}\text { Moisture } \\
\text { Contem } \\
\%\end{array}$} \\
\hline & & $\begin{array}{c}\text { Fodder } \\
\text { units, } \mathrm{kg}\end{array}$ & $\begin{array}{l}\text { Digestiblc } \\
\text { protein, } \\
g\end{array}$ & $\begin{array}{l}\text { Calcium, } \\
\mathrm{g}\end{array}$ & $\begin{array}{c}\text { Phos- } \\
\text { phorus, g }\end{array}$ & $\begin{array}{c}\text { Carotene, } \\
\text { ng }\end{array}$ & \\
\hline Aspen leaves & 13 & $0.25-0.34$ & $\begin{array}{l}17.0^{-} \\
32.0\end{array}$ & $\begin{array}{l}3.83- \\
14.92 \\
\end{array}$ & $\begin{array}{l}0.68- \\
1.52 \\
\end{array}$ & $28-75$ & $\begin{array}{l}51.4- \\
63.1 \\
\end{array}$ \\
\hline Aspen stalks & 11 & $0.14-0.24$ & $9.0-19.0$ & $\begin{array}{l}3.15- \\
10.26\end{array}$ & $\begin{array}{l}0.59- \\
0.95\end{array}$ & n. d. & $\begin{array}{l}47.5- \\
58.3 \\
\end{array}$ \\
\hline $\begin{array}{l}\text { Shoots of } \\
\text { young aspen } \\
\text { scions (stalks } \\
+ \text { leaves) }\end{array}$ & 8 & $0.29-0.35$ & $\begin{array}{l}18.25- \\
28.88\end{array}$ & $\begin{array}{l}3.86- \\
6.47\end{array}$ & $\begin{array}{l}0.86- \\
1.24\end{array}$ & $33-64$ & $\begin{array}{l}57.2- \\
64.5\end{array}$ \\
\hline Alfalfa & n. d. & $0,17-0,22$ & $38-40$ & 4,5 & 0,7 & $29-96$ & n. d. \\
\hline Allalfa & n. d. & 0,24 & 34,0 & $\begin{array}{c}5,04 \\
119,3^{*} \\
\end{array}$ & $\begin{array}{l}0,64 \\
12,5^{*}\end{array}$ & $\begin{array}{l}46,0 \\
\pm 4,2\end{array}$ & 74,2 \\
\hline Alfalfa hay ${ }^{* * * *}$ & n. d. & 0,49 & $87-101$ & 14,37 & 2,21 & $20-86$ & $17: 0$ \\
\hline
\end{tabular}

*) Under absolutely dry moisture.

**) SHCHEGLOV, BQYARSKY, 1990; ZIPER, 2003.

***) TSAREV, MironenKo, 1993.

*****) AVRAMENKO, 2003; ZIPER, 2003.

n. d. - no data.

\section{Conclusion}

- The aspen is a widely distributed and important deciduous forest species in Russia.

- It is very sensitive to attack of heart rot so the main object of its domestication is the selection of the most productive and resistant forms.

- Some of the aspen stands selected in Central Chernozem zone showed high resistance to heart rot attack. The mean volume of sound wood of these stands was many times larger than that of the usual stands. More accurate data can be obtained in the course of research including special progeny tests.

- The wood density of selected heart rot resistant stands didn't differ from that of usual control ones. The other mechanical wood properties (the compression strength along fibers and the strength at static bend of the heart rot resistant stands) were average between minimal and maximal value of that characteristics.

- The local aspen hybrids in Voronezh region had the volume of wood of $300-500 \mathrm{~m}^{3} /$ ha at the age of 29 years with very high output of sound wood.

- The food value of aspen leaves was close to that of fresh mass of alfalfa.

- As a whole, the aspen presents a valuable resource of wood and possesses other useful characteristics. Rational use of this aspen potential can bring in an essential contribution to transformation of forest cultivation in this high revenue branch of the country economy.

\section{Acknowledgements}

The author would like to thank R. TSAREVA and V. TSAREV for their help to collect and processing the aspen hybrid data. The author also extend thanks to
T. Blagodarova and staff of the fodder laboratory of Voronezhsky Regional Agriculture Chemical Station for the aspen green mass analyzing and to O. DoBRYNINA for translation editing of Russian variant of manuscript. My special gratitude is to well known poplars breeder BRIAN J. STANTON from Green Wood Resources (Portland, Oregon, USA) for his thorough editing manuscript and making many important scientific advises, comments and remarks which accounting allow to improve significant this manuscript.

\section{References}

Avramenko, V. I. (2003): Feed and feeding of livestock and poultry. AST Publishing House, Moscow end Stalker, Donetsk. (In Russian).

BACHOFER, M. and J. MAYER (2007): Drzeva. Tlumaczenie z niemieckiego H. Panayiotopoulos. MULTICO Oficyna Wydawnicza. Warszawa. (In Polish).

BAKULIN, V. T. (1966): Triploid clone of aspen in the Novosibirsk region forests. Genetics. No. 11. S. 58-68. (In Russian).

BAKULIN, V. T. (1969): The breeding characteristics of aspen forests of southern taiga forest growing district of the Novosibirsk region. Abstract of candidate of biological sciences. Krasnoyarsk. (In Russian).

Börset, O. (1960): Silviculture of aspen. Scott. For. 14. 68-80. (In English).

DAVID, A. (2003): Aspen/Larch Genetics Cooperative. Annual Report. Department of Forest Resources, University of Minnesota, North Central Research and Outreach Center. (In English).

Desroshers, A., R. Driessche and B. R. Thomas (2003): Nitrogen fertilization of trembling aspen seedlings grown on soils of different pH. Can. J. For. Res. 33. 552-560. (In English).

DisTRIBUTION of the forest area and wood stocks on prevailing species and groups of age at 01.01.2011. M: Federal Forestry Agency of Russia. (In Russian). 
Eliseev, S. G. and V. N. ERmolin (2008): Physical \& mechanical properties of wood at different Populus tremula forms. www.science-bsea.bgita.ru/2008/ leskomp/eliseev-fiz.htm (In Russian).

Fungal Databases/Nomenclature and Species banks/ Online Taxonomic novelties submission (2004-2012 Mycobank) (http://www.mycobank.org/MycoNaxo.aspx? Link=T\&Rec=267652). (In English).

HEINZE, B. and B. Fussi (2010): A first look of Aspen (Populus tremula) phylogeography across Eurasia. P. 18 Fifth International Poplar Symposium: Poplars and willows from research models to multipurpose trees for a bio-based society (20-25 September 2010), Orvieto (Italy). (In English).

IvANNIKOV, S. P. (1952): Fast growing and rot resistant aspen forms. Forestry. No. 12. S. 37-38. (In Russian).

IvANNIKOV, S. P. (1958): Breeding of aspen in central steppe for rapid growth and resistance to rot. S. 94-99. Fast-growing and economically valuable species. Ed. Ministry of Agriculture of the USSR. Moscow. (In Russian).

JoHnsson, H. (1942): Cytological studies of triploid progenies of Populus tremula. A new giant Populus tremula in Norbotten. Hereditas. V. 28. No. 3-4. P. 306-312. (In English)

KREMER, B. P. (1998). Die Bäume Mitteleuropas: welches Blatt ist das? 2. Aufl. Stuttgart: Kosmos. (In German).

Melander, I. (1938). A new giant Populus tremula in Norbotten. Hereditas. V. 24. No. 1-2. P. 189-194. (In English).

MelekHov, I. S. (1980). Forest Science: text-book for high school. Moscow: Lesnaja Promyshlennost. 406 p. (In Russian).

Nilsson-Ehle, H. (1936): Über eine in der Natur gefundene Gigas-form von Populus tremula. Hereditas. B. 21. H. 2-3. S. 379-382. (In German).

PogrebnyaK, P. S. (1968) General Forest Science. Kolos. Moscow. (In Russian).

RAzUmov, V. A. (1986): Reference laboratory chemist to analyze the feed. Rosselhozizdat. Moscow. (In Russian).

ShCHEGlov, V. V. and L. G. Boyarsky (1990): Foods: Cooking, storage and use. Agropromizdat. Moscow. (In Russian).

Schreiber, S. G., U. G. Hacke, A. Hamann and B. R. Thomas (2011): Genetic variation of hydraulic and wood anatomical traits in hybrid poplar and trembling aspen. New Phytologist Trust. N 1. P. 1-11. (www.newphytologist.com). (In English).

ThOMAs, B. R. (1997): Variance components, Heritabilities and Gain Estimates for Growth Chamber and Field Performance of Populus tremuloides: Gas Exchange Parameters. Silvae Genetica 46. No 6. P. 309-317; 317-326. (In English).

TREES and Shrubs of the USSR. (1951). T. 2. Academy of Science of USSR. Moscow - Leningrad. (In Russian).

TSAREV, A. P. (1970): Breeding of aspen in the Voronezh region. S. 346-352 in the book Forest genetics, breeding and seed production. Publisher „Karelia“. Petrozavodsk. (In Russian).

Tsarev, A. P. (1985): Cultivarology of poplar. Publisher Voronezh University. Voronezh. (In Russian).

Tsarev, A. P. and S. S. Mironenko (1993): Feeding value of green mass of leaves in minirotation plantations. Voronezh: Voronezh Research Institute of Forest Genetics and Breeding. Dep. VINITI 15.11.1993. No. 2829 - V 93. (In Russian).
Tsarev, V. A. and A. P. Tsarev (2010): The white poplars testing in Central Chernozem region. P. 160-161. Eurasian Forests - Podmoscovny vechera: Materials of the X International Conference of Yung Scientists, dedicated to the $90^{\text {th }}$ anniversary of the Moscow State Forest University foundation and to the $170^{\text {th }}$ anniversary of Prof. M. K. Tursky's birth. Moscow State Forest University. Moscow. (In English).

Tsarev, A. P., V. A. Tsarev and R. P. Tsareva (2011): Aspen - a forest weed or source of valuable raw materials? P. 162-163.//Conservation of Forest Genetic Resources in Siberia: Proceedings of $3^{\text {rd }}$ International Conference (August 23-29, 2011, Krasnoyarsk, Russia). V. N. Sukachev Institute of Forest SB RAS. Krasnoyarsk. (In English).

Tsareva, R. P. (2003): Breeding of aspen. P. 334-351 in the book A. P. Tsarev, S. P. Pogiba, V. V. TRenin Breeding and reproduction of forest trees. „Logos“. Moscow. (In Russian).

Tyurin, A. V., P. V. Voropanov and I. M. NAUmenko (1956): Forest auxiliary book (on forest inventory). Edited by A. V. TYRIN. $2^{\text {nd }}$ edition. Goslesbumizdat. Moscow - Leningrad. (In Russian).

UNSELD, R. voN and G. VON WÜHLISCH (2012): Die Aspe als Vorwaldbaumart: UNSELD, R. und BAUHUS, J. (Hrsg.) Ergebnisse aus Anbauversuchen von Neuzüchtungen. Schriftenreihe Freiburger forstliche Forschung-Band. Waldbau-Institut Albert-Ludwig-Universität Freiburg. S. 38-51. (In German).

VANIN, S. I. (1955): Forest phytopatology. Goslesbumizdat. Moscow-Leningrad. (In Russian).

YABLOKOV, A. S. (1941): Giant form of aspen in the USSR forests. Proceedings VNIILH, vol. 23. Pushkino, Moscow region. (In Russian).

YABLOKOV, A. S. (1949): Raising and breeding of healthy aspen. Goslesbumizdat. Moscow. (In Russian).

YABLOKOV, A. S. (1963): Raising and breeding of healthy aspen. Goslesbumizdat. Moscow. (In Russian).

YAKIMOV, I. V.: Structure and physic mechanical properties of wood. The doctoral thesis abstract. Voronezh: Voronezh Forest Technical Institute, 1964. 24 pages. (In Russian).

WorRell, R. (1995): European aspen (Populus tremula L.): a review with particular reference to Scotland. II. Values, silviculture and utilization. Forestry 68. No 3. P. 231-243. (In English).

WÜHLISCH, G. VON (2006): Ergebnisse der Züchtung von Pappeln und Aspen in Großhansdorf - Perspektiven für die energie- und Rohstofferzeugung: Vortr. Pflanzenzüchtung. 70, Göttingen. S. 157-172. (In German).

WÜHLISCH, G. VON (2009): Eurasian aspen - Populus tremula: EUFORGEN Technical Guidelines for genetic conservation and use for Eurasian aspen (Populus tremula) Bioversity International, Rome, Italy. 6 pages. (In English).

Wuehlisch, G. VON (2010): Growth Performance of F1Hybrids, Backcrossed Hybrids and F2-Hybrids of Populus tremula and Populus tremuloides. Fifth Intern. Poplar Symp. Poplars and willows: from research models to multipurpose trees for a bio-based society, Orvieto, Italy. Sept. 20-25 2010. Book of Abstracts, p. 37. (In English).

ZIPER, A. F. (2003): Feed and feeding of domestic animals. AST Publishing House, Moscow end Stalker, Donetsk. (In Russian). 